\title{
ON THE PITFALLS OF A DEVELOPMENTAL STATE
}

\author{
Mzukisi Qobo \\ Department of Political Sciences \\ University of Pretoria, South Africa
}

\section{Introduction}

Economic transformation has always been the cornerstone of the governing party since it assumed power in 1994. The notion of a developmental state has since the early 1990s been used as a catch-all phrase for the African National Congress (ANC) thinking on economic and social policies. There is even a subcommittee within the ANC called the Economic Transformation sub-committee, which is seen as the custodian of the ruling party's vision for socio-economic change, as well as offering broad guidelines for a range of policies that have to do with the economy. Over the years since the ANC came into power in 1994, the idea of building a developmental state has continued to serve as an organising principle to frame the nature of change desired by the government. It is a notion that is conceptually ambiguous and lacking in precision with respect to policy application.

According to Pempel (1997: 139), developmental states "define their missions primarily in terms of long-term national economic enhancement", and "they actively and regularly intervene in economic activities with the goal of improving the international competitiveness of their domestic economies". According to this definition, the imperative for managing structural change domestically, for example, improving the growth profile of the economy, diversifying the production base, and generating employment is pursued alongside strategies to promote the country as an investment destination to foreign capital.

In many instances, the emphasis placed by the governing party on the notion of the developmental state stresses a more teleological thrust expressed in a certain state of completeness, and usually in reference to the typology of East Asian countries. Beyond rhetoric, it is 
worth probing what exactly does 'developmental state' mean in the post1990 South African context, a period characterised by increasing global integration and emergence of 'footloose' capital favouring locations where the state is seen as less interventionist.

\section{Conceptual map}

By the time that South Africa started its transition from apartheid to democracy in the early 1990s, the pendulum of economic thinking had shifted globally and strongly towards neoliberal restructuring as an article of faith for economic policy making. This came in the wake of the oil crisis of the early 1970 s and the attendant recession of the 1980s. In much of the developing world the state was in retreat, and giving way to a deregulation and liberalising agenda that would presumably stem the crisis. To prove its credentials as a responsible international citizen, South Africa drew heavily on the major themes of the Washington Consensus, in both its pure (laissez faire) and augmented versions (a blending of regulatory features and free markets).

Given the centrality, though, of the trade unions in the struggle for liberation, and their closeness to the new governing party in South Africa, measures such as flexible labour markets were ignored in favour of a much tighter legislative regime that included the Labour Regulation Act of 1995 and a welter of worker-friendly measures that followed, including the Basic Conditions of Employment Act and Employment Equity Act, amongst others.

Trade unions, especially through the association of the Congress of South African Trade Unions (COSATU) with the governing party, were deeply embedded in the post-apartheid economic policy formulation. This was facilitated by the informally structured tripartite alliance summit that also included the South African Communist Party (SACP) as well as through the more formally structured National Economic Development and Labour Council (NEDLAC) that came into existence in 1995.

While the broader macro-economic policy framework was crafted in a way that was sensitive to international capital, the more specific and sectoral policy arrangements were oriented more closely to trade unions as a powerful political constituency of the governing party. The external environment within which South Africa negotiated its domestic economic restructuring and participation in the global economy was less favourable to state interventionist approaches to development. 
In a sense, the South African government could not behave in a voluntary manner as if there were no strictures; neither could it act as if its agency was entirely constrained. It needed to carefully tread the path between elements of its constituency that were grounded in left politics, and the investor community that could not care less about the political and socio-economic constraints South Africa faced post-apartheid.

Against this backdrop, the South African governing elite adopted the rhetoric of 'developmental state' as a mantra for social and economic policy whilst the substance of economic policy-making conformed more to Washington Consensus modes of thinking. Johnson (1999: 53), who is widely credited for coining the 'developmental state' concept, observed that: "The source of authority in the developmental state is not one of Max Weber's 'holy trinity' of traditional, rational-legal, and charismatic source of authority ...". Developmental states, according to Johnson (1999: 53), are marked by the existence of "a revolutionary authority: the authority of a people committed to the transformation of social, political, or economic order". Johnson further suggests that there is little that differentiates the leaders of a developmental state to those leading mass movements.

This imagery is resonant with the character of South Africa's governing party as it struggles to accommodate both a mass movement character and a desire to become a modern political party. The impulse of the 'developmental state', as such, is nestled in the former, while the latter appears to seek a more open, outward-oriented, democratic country. The major challenge faced by the governing party has to do with the character of the international environment that disciplines economic policy forms that diverge from the Washington Consensus. The very identity of the ANC as a nationalist and mass-based party predisposes it towards policy positions that resonate with the poor, the unemployed and the working class. Rhetoric aside, such a stance, however, does not mean the state over which the ANC presides is developmental. It is just that the promise of a developmental state appeals more to this segment of the population. It is a dream or a destination that seems possible via a political agency that they regard as revolutionary in character. Whether this is, indeed, possible in the conditions that prevail in South Africa, is something that is least interrogated in political debates.

Such constraints go beyond the reality of available resources of capacities, but also entail the divergent ideas and perspectives that 
exist in a pluralistic society that South Africa is, about the best possible pathways to economic success. Unlike in Asia where there is a considerable degree of homogeneity, as well as existence of a political agency that was authoritarian during the high growth phase of these countries, South Africa is politically diverse, ideologically plural, and boasts a liberal constitution. The state cannot degree a raft of legislative measures to achieve what it considers grand objectives. These have to be contested in parliament and in many instances within the tripartite alliance. For a state to pursue a programme that is defined in radical and undifferentiated terms it requires huge political leverage, uncontested legitimacy, or a dose of authoritarianism, the conditions of which do not exist in South Africa.

It is likely that states, moving from a certain implicit understanding of their role as developmental states, for example adopting some of the features of East Asian economies, may develop an approach which they consider most suited to their domestic context and one that is sensitive to global forces. South Africa has displayed an occasional political tendency towards developmentalism. But since its economic policies are broadly outward oriented and display a lack of domestic economic priorities in terms of investment and employment creation, the nature of the external engagements in actual fact re-confirm liberalism both at home and abroad. One could say that the discrepancy between declared policy goals and practice turns it in terms of socioeconomic policy into a hybrid state - at once leaning towards state interventionism and toning down to please domestic and global business actors.

\section{Developmental state creation in South Africa?}

In South Africa the notion of a developmental state can be traced to the ANC's earlier policy thinking crystallised in a document called Ready to Govern (ANC 1992) formulated in 1992. In this document the ANC set out what it regarded as policy guidelines on the future developmental state. It asserted that the developmental state would "have ultimate responsibility - in cooperation with the trade union movement, business and other organs of civil society — for coordinating, planning and guiding the development of the economy towards a sustainable economic 
growth pattern. Emphasis will be placed on macro-economic balance, including price stability and balance of payments equilibrium".

Along this theme of a developmental state, the party promised to implement an economic policy with two principal components:

- Redistribution programmes to meet the basic needs of our people. A priority in this regard will be the provision of basic senvices, affordable housing and infrastructure ...

- The restructuring of the South African economy on the basis of new, comprehensive and sustained growth and development strategies in all sectors of the economy.

The pressure to formulate a policy approach that leans heavily towards the interests of the poor originated in the very fact of the prevailing social structure in South Africa, in particular the reality of material dispossession of black people by centuries of colonialism and apartheid. The resultant redistributive and populist posture was further articulated in detail in the ANC's first economic policy - the Reconstruction and Development Programme (RDP), which was adopted in 1994, and later to be abandoned in favour of the more liberal-oriented Growth, Employment and Redistribution Plan (GEAR).

In South Africa it would appear that debates within the ruling party on the concept of a developmental state are less about the substantive meaning of this concept as rooted in the actual experiences of East Asian economies, but more about rhetoric and piecemeal policy measures. It is not substantive in the sense of it being a systematic framework for economic governance or a clearly defined policy approach that can lend itself to measurable implementation. This rhetoric is at two levels. First, it is meant to underline the importance of greater state involvement in the economy using both regulatory instruments and up-scaling the activities of development finance institutions and state-owned enterprises. Second, it is a concept that has political instrumentality, namely to solidify ideological consensus within the ruling alliance, and to cement the imaginations and allegiance of the poor to the ruling party.

On the first dimension, the ANC's economic transformation discussion document argues that, "[i]n the twentieth century, the developing countries that succeeded in promoting industrialisation, sustained growth and development have all had in common developmental states that played a leading role in infrastructure programmes and which had 
an active industrial policy" (ANC 2007: 6). This document further suggests that the state should play a central and strategic role, but does not elaborate as to what this might actually entail in practice.

Accordingly, the image of the state as an activist or entrepreneur is central in the definition of a 'developmental state' within the ruling party. But, having an industrial policy in place does not make a state developmental. It could also be argued that state interventionist measures are not synonymous with development; the test is how the structure of the economy has shifted and economic resources were distributed. The size of the country's state-owned entities or of its development finance institutions can also not be used as yardsticks for a developmental state. It is less about the available resources that matter, but how these are deployed or distributed to generate social and economic value. In the East Asian cases, the political order, the process of economic change, and the outcomes were crucial signifiers.

The paradox of the developmental state lies in the fact that for the state to be effective it has to maintain relative autonomy from particularistic interests, something that is evidently difficult in the context of a ruling party that works within a framework of contending interests in the tripartite alliance with COSATU and the SACP, as well as within the framework of a diversity of economic stakeholders within NEDLAC.

In any case, South Africa is a pluralistic democracy that cannot be neatly characterised as a developmental state. Political contestations do not only exist between divergent political parties, but more intensely within the ruling party. Two years after the ANC had adopted the Ready to Govern document, it had formulated a Reconstruction and Development Programme, and COSATU played a central role in giving it shape. Hardly two years later, the RDP had ceased to be a programme that guided government's social and economic strategies. A market-oriented and liberal leaning economic policy was adopted in its stead - the Growth, Employment and Redistribution framework.

This liberal leaning approach to economic management was preceded by a reflective document, called the State and Social Transformation, that was widely believed to have been authored by Thabo Mbeki (then Deputy President), and was presented at the Alliance Summit in 1996. The document set out what would become the policy outlines of a new approach to economic policy and the state's role therein (ANC 1996). It presented the stark options that the new government had to contend with, alluding to the importance of courting 
capital for investment and defining the role of the state as that of mediating the tensions between capital and labour.

This document drew spirited criticism from the leading lights of the SACP, Blade Nzimande and Jeremy Cronin. In their rejoinder, they called for a state that is not merely regulatory but 'developmental', 'active', and 'catalysing' (Nzimande and Cronin 1997). Further, they criticised what they saw as a technocratic approach to governance. Their own solution was to clamour for maintaining antagonistic relations between capital and labour, and the overthrow of capitalism to pave the way for socialism.

These critical views were brushed aside for their starry-eyed impracticality. For the first time, and early on in South Africa's democracy, the governing elite elaborated a modernising agenda and articulated a policy position that was less state-centric and friendlier to the private sector. This also reflected a new dynamic where the emergent state elites had to spend more time with big business than they ever did before. Further, they were socialised into global institutions were the predominant ideology favoured certain ideational orientation to economic policy making. This perspective was at odds with the ANC's alliance partners, COSATU and the SACP who championed stateinterventionism, and broadly leftist positions.

The discussion paper that foregrounded GEAR was never adopted as the official ANC or alliance policy paper. Its main ideas, however, underpinned the government's economic policies between 1996 and 2002, without any direct reference to it. Interestingly, Mbeki quoted extensively from this paper during his opening address at the ANC's National General Council in June 2007 - the penultimate gathering that paved the way for his downfall six months later in a palace coup engineered by COSATU and the SACP.

Possibly, the seeds of the chasm between the two centres of power - the ANC in Luthuli House and its left-leaning allies on the one hand, and the state (the Union Building) on the other, could very well be traced to the battle of ideas represented in the rejection of the State and Social Transformation document by the ANC's alliance partners on the left. It is the ideas contained in this document that accentuated the ideological tensions within the ANC. The political backlash to the somewhat 'authoritarian' fashion with which the ANC proceeded in casting these ideas in government is evidence of just how difficult it is to implement a modus vivendi and economic strategies that could be defined 
as essentially developmental.

Significantly, the paper did not directly refer to the notion of a 'developmental state', but stressed the concept of a 'democratic state'. This suggests a tension between the two concepts, and the fact that in its original meaning, rooted in Asian experiences, the concept of developmental state has little resonance with democratic repertoires. It is worth underlining that not once did Mbeki refer to the notion of a 'developmental state' at the National General Council in 2007. He may just not have believed strongly in this notion, especially given its association with a more authoritarian bureaucratic rule. Those who formed the layer of state elites under Mbeki were also less attracted to this notion. However, those who were outside of the state continued to draw out the lines of difference and attacked what they saw as a neoliberal posture of the state. These ideological tensions were not inconsequential for the state.

Fundamentally, they were a mirror of deeper problems of the vision and institutional organisation of the state to carry out a clearly defined vision. Below I sketch some of the tensions that have marked the policy terrain of the state, in particular in regard to the later shifts from the Accelerated and Shared Growth Initiative (ASGISA) to the New Growth Path (NGP) and to what is broadly characterised as radical economic transformation marking President Jacob Zuma's second term in office.

\section{From GEAR to the unknown}

The first phase of South Africa's political transition and economic policy processes devoted much of its attention to macro-economic reforms and adjusting the domestic policy environment to the global economic landscape. South Africa had constrained options as it sought to gain acceptance by Western countries and show itself ripe for foreign direct investment. There was an immediate shift towards trade openness and active promotion of participation in a liberal and rules-based global trading system.

The offer that South Africa made to the General Agreement on Tariffs and Trade (GATT) as part of its accession in 1993 was a demonstration of the country's keenness to integrate into the global economy. At a technocratic level, this phase also represented a period of learning policy formulation and institutional development, in particular with re- 
spect to fiscal, monetary, trade, and competition policies. Best practices related to the first three sets of policies were those available from advanced industrial economies. The institutions that South Africa drew lessons from, for example the World Bank and the International Monetary Fund (IMF), were those over which advanced industrial countries had ideological preponderance.

At the time, there was real pressure, given the ailing state of the economy, to stabilise macro-economic aggregates and government finances if social spending was to be sustainable in the future. The South African economy achieved only a paltry 1.4 per cent average growth rate between 1980 and 1994, and was plagued by double-digit inflation. Joblessness was also on the rise, with the unemployment rate at nearly 25 per cent (fairly similar to current levels), raising the spectre of future social instability. Moreover, the size of the Gross Domestic Product (GDP) in 1994 was less than US\$80bn - too small for the country to make any dent on levels of social marginalisation suffered by the majority of South Africans.

From the new government's point of view, macro-economic stability was seen as important for framing an outward-oriented strategy that would not only attract investment but also hopefully drive up exports, with job creation as an expected outcome. It is in this sense that voluntarism in economic policy-making was constrained, but as alluded to before, this did not foreclose creativity or innovate thinking on achieving developmental goals. With the exception of a few policy outcomes such as expanding social welfare provision, there is little evidence that institutions were, over time, calibrated to expand the horizons of policies that could help expand economic activities or even address deep-seated social inequalities.

As noted in the previous section, much of the liberal economic thinking was defined in the State and Social Transformation document of the ANC, and GEAR in government. This liberal reform agenda was highly oversold, raising unrealistic expectations about what was possible within a short period of time. Some of its basic outlines and targets included improving the competitive profile of the economy; expanding the private sector for capital formation; ensuring infrastructure development and service delivery; introducing some flexibility in the labour market; ensuring fiscal deficit reduction; achieving growth rates of six per cent by 2000 , and improving the employment rate through the creation of 400000 jobs per annum during this period. While there was 
a commitment to the article of faith of this policy approach, its targets in terms of higher growth rates and job creation were not achieved.

The premium placed on the stabilisation programme necessitated a toning down of the 'basic needs' approach advocated in the Reconstruction and Development Programme (RDP) which was the ANC election manifesto launched in 1994, and which enjoyed popular support amongst the workers, the unemployed, and the poor in general.

In hindsight, this 'constrained discretion' expressed in GEAR would later help the Minister of Finance in increasing public expenditure, especially in directing resources towards infrastructure development, education, health, housing and other basic social services. Yet still this did not match the earlier enthusiasm about creating a developmental state.

In Mbeki's second term of office, commencing in 2004, the economic reform agenda turned to focus on micro-economic problems. More emphasis was placed on integrating the 'Second Economy' into its more developed, and formal sector counterpart. ASGISA was an economic policy frameowork launched in July 2005 to frame government's micro-economic reform strategy and focus attention on specific sectors of the economy. At the core of ASGISA was the aim to ensure sustainable growth at six per cent per annum by 2009 , and to halve poverty by 2014.

The economic sectors that ASGISA prioritised included agriculture, mining, tourism, cultural industries, information technologies, clothing and textiles, vehicle manufacturing, aerospace sector, call centres and back office business processes. The focus of the strategy at the domestic level was to ensure greater value addition in production, as well as gaining competitive advantage in the services sectors.

ASGISA architects used the methodology of binding constraints in the economy as a way to prioritise interventions that would optimise growth. Some of the binding constraints it prioritised included: cost, efficiency and capacity of the national logistics system; barriers to entry, limits to competition and limited new investment opportunities; regulatory environment and the burden on small and medium businesses; deficiencies in state organisation; and capacity and leadership.

Government's planned intervention to these binding constraints fell into five categories: infrastructure programs; sectoral interventions; skills and education initiatives; Second Economy interventions; macroeconomic issues; and public administration issues. As an economic 
policy framework, ASGISA was underpinned by a sectorally focused industrial policy, with support to the manufacturing sector and broad diversification of the formal economy as the primary focus.

From a capacity point of view, it is doubtful if the government had sufficient resources at its disposal to drive a sectoral-based industrial policy process. Insufficient coordination, capacity constraints, and poor resource mobilisation undermined policy effectiveness. There was also lack of consensus within the ruling party and its allies on the left about the direction of economic change. The shift of focus from macroeconomic to micro-economic intervention was mainly rhetorical and resulted in a variety of governmental procedures, including the new emphasis on coordination, but turned out to be very low in terms of substance.

In December 2007, two years after the adoption of ASGISA as government programme, Mbeki lost his grip on the party, and eight months later he was removed from office as the country's president. Policies such as ASGISA disappeared along with the shift in the political order within the ANC and government. President Jacob Zuma's emergence as President of the ANC in December 2007 and that of the country in May 2009, signalled another shift of rhetoric in economic policy. During Zuma's first term in the presidency, the NGP eclipsed ASGISA in the same way that GEAR had earlier overshadowed the RDP.

\section{The New Growth Path: Towards radical economic transformation?}

The NGP was adopted as the centrepiece of government's development strategy in 2010. Since then it has become the defining kernel of South Africa's developmental state vision along with attendant policy instruments such as the industrial policy framework crafted by the Department of Trade and Industry (DTI). It is a policy approach that is also associated with the rising influence of COSATU and the SACP in government. Ebrahim Patel, former union leader, became the architect of this policy approach in government under a newly created ministry of Economic Development.

This NGP was, like its predecessors, aimed at overcoming structural weaknesses in the economy. Its overarching vision was to generate five million jobs by 2020. It aimed to achieve this by stimulating the labour-absorbing capacity in the economy, and with reference to a low- 
carbon development trajectory.

Government's role is defined in Patel's plan as that of providing infrastructure; skills; and an efficient and effective regulatory environment. The four areas of intended impact are set out as follows: the formal sector; small and micro sector; the social sector; rural development; and Africa's economic development. The plan contained little substance as to how the state would generate impact or measure success in some of these areas.

For the first time, during this phase development finance institutions were assigned an explicit developmental mandate. Increasingly, the South African government came to view its developmental finance and state owned enterprises as instruments aimed at achieving a range of objectives intended to improve quality of life; enhance public service delivery; increase economic growth; improve infrastructure; and create jobs - elements that, according to the recent report of the Presidential Review on State-Owned Enterprises, constitute a 'developmental state' (Presidential Review Committee on State-Owned Enterprises 2012).

Since 2010, the Industrial Development Corporation (IDC) has been recalibrated to work within the political strictures of the Economic Development Department that, along with the DTI, drives the state's interventionist agenda under the rubric of the national industrial policy framework. Accordingly, job creation has become the central aim in the IDC's core mandate, a shift from defining its development mandate in broad generalities and committing its investments for the purpose of realising high returns. Further, the IDC is also expected to fulfil some of the goals set out in the NGP.

This new economic policy approach or even the repositioning of the country's development finance institutions and State-Owned Enterprises (SOEs) does not necessarily imply coherence in government's core thinking about what it aims to achieve overall, but it is at least indicative of the general impulse of the country's development strategy. Some of its objectives are rehashed from previous plans; and much of its achievements are dependent on what other government departments and agencies do.

This new policy approach is yet another indeterminate compass in search of an elusive developmental state dream. Whereas in the initial phases of policy development, especially between 1994 and 2002 , there was a very sharp battle of ideas outside of government, the 
current phase is characterised more by a battle of control over the levers of state power. Policy thinking is ad hoc and tends to mirror factional tensions within the governing party. Governance has, as a result, also lost its steadiness. The very institutional pillars that are critical for shaping a 'developmental state' are either weak or dysfunctional. Discourse on the developmental state in the current juncture is incongruous with the reality of the character and quality of requisite institutions.

\section{Next steps for South Africa?}

The pressure on the South African state to produce significant socioeconomic change in the immediate to short term is great. This goes beyond the challenge of restructuring the economy, and often presents the state with stark choices. One such tension is that existing between the need to build a growing and competitive economy while at the same time addressing the concerns of its main constituency for strong redistributive policies. Moreover, this plays out in an environment where the authority of the ruling elite is under challenge from within the ANC itself, and where the state in its current democratic form is still fragile

This is not helped by the fact that the historical lineage of the present day ruling elite is rooted in mass mobilisation: its largest constituency is made up of the unemployed, the poor and the working class. Yet it must maintain an appeal to South Africa's substantial middle-classes and powerful big business sector. The ANC elite cannot simply impose its will on civil society; it can only negotiate its options for economic change. Policy positions that are aimed at benefiting one constituency at the expense of the others are likely to have a polarising effect and generate a backlash from those who are excluded from the formal economy. This is a major dilemma faced by a governing party seeking to build a developmental state.

It is possible that South Africa could draw many important lessons from the original developmental states of East Asia, such as the sequencing of policy reforms; managing industrial change and building national economic competitiveness (micro-economic reform); balancing efficiency and equity considerations; maintaining a broadly outwardoriented posture; and effecting 'horizontal interventions' in areas such as Research and Development (R\&D) support, human capital formation, and infrastructure development.

Most of all, South Africa can work towards building a more 
efficient, effective, meritocratic bureaucracy - a crucial element in achieving the goals of a transformative (developmental) state. At issue here is the need to professionalise public services, which would require abandoning the unproductive rent-seeking approach of 'deploying' party cadres to government. As Evans (1992: 22) has pointed out, a state that is endowed with technocratic and administrative capacity has more latitude for policy options than those with weaker bureaucracies.

Southall (2006: xvii) suggests that there are three imperatives that South Africa would have to address if it is to transform into a developmental state. These are related to its human resource capacity constraints; limits posed by globalisation and the combination of low levels of social coherence and low levels of development - both inherited from the apartheid era. In this respect, he argues, South Africa has to "combine development and democracy". It is difficult to point to any example in the developing world outside of Asia that has achieved this feat, especially in the era of contemporary globalisation and interdependence in which South Africa has to make its economic policy choices.

While prioritising development is not a choice but a necessity for a country whose society is acutely torn along racial and class lines, there is no simple answer as to what character and form such a development strategy should assume. A look at South Africa's journey since it attained democracy in 1994 reveals not only the complexities of managing political and socio-economic change in the era of globalisation, but also sheds some light on the possible paths or linkages between various options that South Africa might explore.

Two decades since it attained democracy, South Africa is now seriously reconsidering the merits of the 1990 s economic reform project. There is a clear shift to populist-type rhetoric, with radical economic transformation featuring prominently in various government policy pronouncements. The momentum generated in the early years of democracy for rapid liberalisation and stabilisation has waned in the face of a lack of anticipated results. This proved that 'Washington Consensus' measures alone are insufficient in generating the necessary drivers of change in societies plagued by deep-seated structural and socioeconomic challenges.

Depending on their nature, and the management of the relationship between various social actors, interventionist policies can either stifle growth or nurture an environment that could generate economic prosperity. The picture that is emerging within South Africa is that of a 
ruling elite that is caught in a tangle of having to satisfy increasingly divergent interests. In such an environment the scope for engaging in far-reaching reforms that could enhance the growth prospects of the country is narrow.

Success also hinges on the ruling elite building broader coalitions for reform, especially focusing on the poor who are not only socially excluded but are also outside of the tripartite alliance of the ANC, SACP and COSATU or the bargaining (NEDLAC) consensus between the state, labour and business. Developing effective channels of engagement with these sectors is not going to be easy given their lack of organisation and the fact that they do not hold a particularly coherent view about reform. The challenge for the state is to clearly demonstrate the benefits of a particular type of economic policy framework.

\section{Bibliography}

ANC (1992), Ready to Govern: ANC Policy Guidelines for a Democratic South Africa, Adopted at the National Conference, 28-31 May.

ANC (1996), The State and Social Transformation. (Available at: http://unw. anc.org.za/show.php?id=306, accessed 06 September 2014.)

ANC (2007), Economic Transformation for a National Democratic Society, ANC Policy Discussion Document for the ANC's $2^{\text {nd }}$ National Conference

Evans, P (1992), "The State as Problem and Solution: Predation, Embedded Autonomy, and Structural Change", in Haggard, S and R Kauffman (eds), The Politics of Economic Adjustment. Princeton: Princeton University Press. Johnson, C (1999), "The Developmental State: Odyssey of a Concept", in WooCumings, M (ed), The Developmental State. Cornell: Cornell University Press.

Nzimande B and J Cronin (1997), "Transformation, Not a Balancing Act", African Communist, No 146, ${ }^{\text {st }}$ Quarter 1999. (Available at: https://amadlandawonye. wikispaces.com/1997,+Nzimande+and+Cronin,+Transformation,+not+a+Bal ancing+Act, accessed 7 September 2014.)

Pempel, T J (1999), "The Developmental Regime in a Changing World Economy", in Woo-Cumings, M (ed), The Developmental State. Cornell: Cornell University Press.

RSA (2012), Presidential Review Committee on State-Owned Entities. (Available at: http://www.thepresidency.gov.za/electronicreport/downloads/volume_2/ volume_2.pdf, accessed 8 September 2014.)

Southall, R (2006), "Introduction: can South Africa be a developmental state", in Buhlungu, S, Daniel, J, Southall, R, and J Lutchman (eds), South Africa 2005 -2006: State of the Nation. Pretoria: Human Science Research Council. 